\title{
"Factors impeding the use of banking services in rural Southern African states"
}

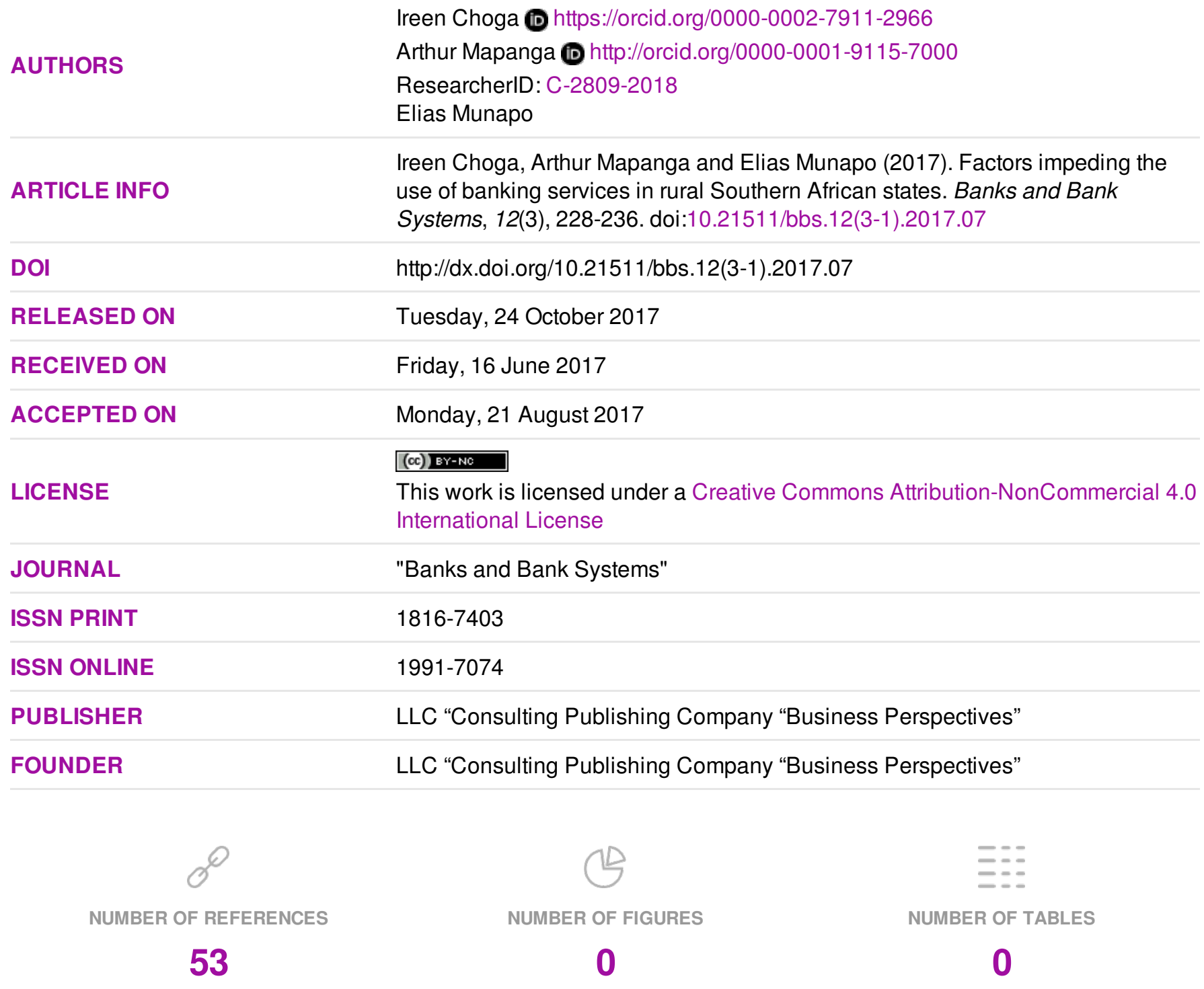

(c) The author(s) 2023. This publication is an open access article. 


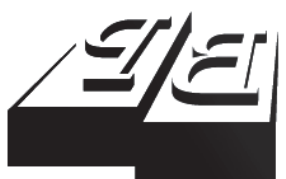

BUSINESS PERSPECTIVES

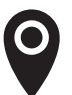

LLC "CPC "Business Perspectives" Hryhorii Skovoroda lane, 10, Sumy, 40022, Ukraine

www.businessperspectives.org

Received on: $16^{\text {th }}$ of June, 2017 Accepted on: 21 ${ }^{\text {st }}$ of August, 2017

(C) Ireen Choga, Arthur Mapanga, Elias Munapo, 2017

Ireen Choga, Prof., School of Economics \& Decision Sciences, North West University, Mafikeng Campus, South Africa.

Arthur Mapanga, School of Economics \& Decision Sciences, North West University, Mafikeng Campus, South Africa.

Elias Munapo, Prof., School of Economics \& Decision Sciences, North West University, Mafikeng Campus, South Africa.

\section{(ㄷ)(1) $(8)$}

This is an Open Access article, distributed under the terms of the Creative Commons Attribution-NonCommercial 4.0 International license, which permits re-use, distribution, and reproduction, provided the materials aren't used for commercial purposes and the original work is properly cited.
Ireen Choga (South Africa), Arthur Mapanga (South Africa), Elias Munapo (South Africa)

\section{FACTORS IMPEDING THE USE OF BANKING SERVICES IN RURAL SOUTHERN AFRICAN STATES}

\begin{abstract}
The paper presents factors why people are reluctant to bank money in rural Southern African countries. Six countries namely Botswana, Namibia, Mozambique, Tanzania, Zambia and Zimbabwe were used in the study. A focus group of 10 people from each of the stated Southern African countries was composed and used to obtain perceptions, views, reactions, attitudes, experiences among others on why people are reluctant to bank their money. People are unwilling to bank their money in rural Southern Africa and the reasons behind this seem to be many. If no correctional measures are put in place, rural Southern Africa will continue to be unbanked for the next five decades.
\end{abstract}

\section{Keywords banking services, unbanked, rural Southern Africa, focus group}

JEL Classification E41, E58, G21

\section{INTRODUCTION}

While the $21^{\text {st }}$ century Africa has achieved impressive GDP growth rates when compared to the rest of the world, Africa is still to achieve inclusive development ostensibly due to the lack of appropriate financial services and instruments that benefit all its people. Extant research shows the importance of financial inclusion as one of the main building blocks of inclusive growth. Yet in Southern Africa, lack of a vibrant banking system means that the region has one of the lowest ratio of adult usage of banking systems. As with the absence of inclusive growth advancing inclusive access to and usage of affordable banking services within the Southern African development community remains a major conundrum. Research (for example, Bruhn \& Love, 2014) defines a vibrant banking system as encompassing supply and demand side initiatives that can allow the provision of suitable and quality financial products that are accessible and affordable to the whole society. Countries in the Southern African development community have generally failed to broaden access to banking services thus failing to mobilize greater household savings, assemble capital for investment, and expand entrepreneurial activity. With over half of the adult population unbanked as of 2014 (Global Financial Development, 2014), Southern Africa thus needs to expand access to and usage of the formal financial services. The aim of this paper is therefore to explore the factors that obstruct the Southern African region population from accessing and using the formal banking system and therefore offer 
recommendations for accelerating progress toward bank use in Southern Africa. The paper is accordingly structured around the questions pertaining to the reasons for financial inclusion through bank use, its meaning and the impediments encountered by both the clients and the financial institutions in Africa in ensuring financial inclusion and the recommendations thereof.

\section{LITERATURE REVIEW}

Evident in literature (Zucarro \& Bridwell, 2016; Diniz, Birochi, \& Pozzebon, 2012; Beck, Demirgüç-Kunt, \& Levine, 2004a) is the fact that inclusive growth is a prerequisite of social and political sustainability all over the world. It is further indicated that the key to inclusive development is financial inclusion. There is no unique definition for financial inclusion in literature as of now as various show differing notions about it. A group of scholars (Kiviat \& Morduch, 2012; Figart, 2013; Johnson \& Williams, 2013; Beck, Senbet, \& Simbanegavi, 2014; Bayero, 2015) view financial inclusion in terms of all working age adults being able to effectively achieve access to credit, savings, payments and insurance from formal service providers such as a banking institution. This stream of thinking argues that effective access means convenient and responsible service delivery at a cost affordable to the customer and sustainable for the providers with the result that financially excluded customers use formal financial services rather than an informal intermediary. Others limit financial inclusion to the delivery of financial services at affordable costs to low-income segments of society (Zucarro \& Bridwell, 2016; Efobi, Beecroft, \& Osabuohien, 2014; Chakravarty \& Pal, 2013). Yet again, to others (Allen et al., 2012; Demirgüç-Kunt \& Klapper, 2013), the use of formal financial services alone adequately constitutes financial inclusion. Lately, Allen, Demirgüç-Kunt, Klapper, and Peria (2016) have refined their perspective to imply that financial inclusion is a reflection of the use of formal banking accounts to benefit individuals.

A closer look at the above definitions indicates some kind of convergence on three key concepts or dimensions of financial inclusion, namely, access (Ramji, 2009; Aduda \& Kalunda, 2012), quality (Demirgüç-Kunt \& Klapper, 2013; Sagib \& Zapan, 2014) and usage (Sarma, 2008; Triki \& Faye, 2013; Demirgüç-Kunt, Klapper, \& Randall, 2014). Thus, this study defines an inclusive financial system as one that maximizes usage and access while minimizing involuntary financial exclusion (as a proxy of quality). In accordance with the work of Cámara and Tuesta (2014), the reduction of the perceived barriers is assessed by the obstacles for those individuals who do not participate in the formal financial system, whereas access and barriers can be used to measure the degree of readiness for financial inclusion with usage being an output of financial inclusion.

Indeed, to achieve the above, a vibrant banking system matters for countries' economic development (Ali, 2016; McKinnon, 2010; Baumol, Litan, \& Schramm, 2007). Literature (for example, Zhang, Wang, \& Wang, 2012) is clear on the causal relationship between the depth of banking as a pillar of the financial system and investment, growth, poverty and total factor productivity. Also, Rousseau and Wachtel (2011) indicate many empirical cross-country tests showing that initial banking system development is included as one of the limited number of robust determinants of the subsequent growth of countries. In the same vein, Anyanwu (2014) cites strength of the banking systems as important for Africa's economic take-off.

Thus, finance as mediated by the banking institutions also matters for the well-being of people beyond the overall economic growth through smoothing individuals' incomes, insuring against risks, and broadening investment opportunities. Without financial inclusion, individuals and firms need to rely on their own resources to meet their financial needs, such as saving for retirement, investing in their education, taking advantage of business opportunities, and confronting systemic or idiosyncratic shocks (Demirgüç-Kunt et al., 2008). This amplifies the importance of well-developed banking systems to poverty alleviation, as well as inequality income reduction (Kim, 2016). These aspects suggest that there may be a strong case for making banking services more generally available. While generally accepted that banking systems play an important role in the socioeconomic wellbeing of society, the Global Findex 
data (Demirgüç-Kunt et al., 2012) confirm vast differences when it comes to the use of financial services such as banks between developed and developing countries and across individual characteristics. According to this study, the proportion of share of adults that own an account at a bank is much greater in the developed economies than the developing economies. Further, it seems that the wealthier and more educated a society is, the more likely that banking systems are used. For example, the Global Financial Development (2014) reports the entire African continent as lagging behind other continents. Yet, as argued in Allen (2016), very little is known about the factors that weaken financial inclusion across individuals and countries. This suggests that the above observations are simply symptoms. There is therefore a need to analyze what the impediments to access are and how access can be improved for the unbanked majority across the world.

Many methodologies are used in literature seeking further understanding of the potential barriers to wider financial inclusion, namely, ethnographic and co-creation methodologies (Aguiar \& Seltzer, 2012), Index of financial inclusion (Sarma, 2010), and Global Findex (2011), to name a few. The Global Findex has gained widespread use in determining the barriers to the use of banking institutions. According to Allen et al. (2012), the Global Findex survey makes use of novel questions to gain insights on the people's reasons for not having a bank account. According to the Global Findex findings, it seems, on a worldwide scale, that the most indicated reason for not owning a bank account has to do with the lack of enough money in the hands of adults for them to be able to use a bank. Allen et al. (2012) ascribe this to the high costs of banking when one considers the meagre and irregular incomes to most of the world adults. This also implies that with the exorbitant service fees charged by banks in most parts of the world, having an account for many is too expensive and unnecessary.

Furthermore, while these self-reported barriers differ considerably across regions, as well as by individual characteristics, in less developed countries, like in those in Sub-Saharan Africa and Latin America and the Caribbean, the most likely cited barrier is lack of documentation (Demirgüç-
Kunt \& Klapper, 2012). In some parts of the world, citizens have little trust in the banks themselves (Benamati \& Serva, 2007; Ehrmann, Soudan, \& Stracca, 2013; Hurley, Gong, \& Waqar, 2014). In the findings of other studies (Felici \& Pagnini, 2008; Brevoort \& Wolken, 2009; Berger, Bouwman, Kick, \& Schaeck, 2016) the distance from the bank is indicated as a huge barrier especially in rural areas.

To improve the banking system, a number of interventions are suggested in literature. According to Yang (2009), the use of technology and other innovations can offset the effect of physical distance as a barrier to the use of the banking system. With regard to the issue of documentation requirements for one to open an account with a bank, some scholars (Cruz et al., 2010; Aljawarneh, Al-Rousan, Maatuk, \& Akour, 2014) recommend that this requirement be relaxed in order to promote banking system especially in Africa where getting such documentation is erratic. The foregoing informs us of the possible barriers to the use of banking services. The next section focuses on the methods applied in this study in order to discover the factors that impede the use of banking services in rural Southern African states.

\section{METHODOLOGY}

To the best of our knowledge, the attempts to classify the factors that impede the use of banking services in Southern African states are scarce and incomplete. Furthermore, the extant literature lacks a comprehensive indication of barriers to banking system use in Southern African states that can bring together such factors by using a statistically sound weighting methodology and accurate information for the countries interrogated in this study. In light of this, focus groups were used to collect data. In this paper, we define a focus group as a gathering of deliberately selected people who participate in a planned discussion that is intended to elicit perceptions about a particular topic or area of interest. Six countries namely Botswana, Namibia, Mozambique, Zambia, Tanzania and Zimbabwe were used in the study. A focus group of 10 people from each of the stated Southern African countries was composed and used to obtain perceptions, views, reactions, attitudes, experiences etc. on why people are reluctant to bank 
their money. Focus groups were used because of the following advantages:

a. focus groups can easily measure the participant's reaction or a group's feeling;

b. focus groups save time and money compared to individual interviews;

c. focus groups offer the opportunity to seek clarification;

d. focus groups provide a wider range of information than individual interviews; group discussions often bring out or reveal additional important information about certain aspects that is not anticipated by the researcher;

e. the researcher can get more information from nonverbal responses such as body language or facial expression.

The results of the study are discussed and presented in section 3 .

\section{RESULTS AND OBSTACLES TO FINANCIAL INCLUSION}

This section provides a general overview of the banking environment focusing on the broad challenges that hinder the demand for and supply of financial services. It discusses the obstacles from the client position followed by those faced by banks. Clearly, the problem of banking services access in Southern Africa requires an urgent need (early adoption) for the use of bank services based on better access to banks, demand from society, public enlightenment, and incentives from the use of bank services.

\subsection{Limited financial literacy}

Prevalent religious and traditional beliefs in the Southern Africa limit access to education. This is quite evident in some apostolic faiths where children are only allowed to access basic primary education deemed enough for understanding basic trade. For Kafela (2010), in a world of escalating financial complexity, there is an increasing need for financial knowledge and at least basic finan- cial skills. Financial literacy implies the ability to make informed judgements and decisions regarding the use and management of money (Jonubi \& Abad, 2013; Huston, 2010). According to Lewis and Lindley (2015), the lack of financial literacy is retrogressive on the ability of people to understand the necessity of saving, borrowing, investing and managing of finance, since financial literacy borders on basic money management skills, that is, budgets, savings, and investments, and insurance. There is an increased diversity of financial products and services, including debt products and investment opportunities available to the public, while providing increased benefits also entails more complex risks. Individuals must be able to differentiate between a wide range of financial products and services, and providers of those products and services. An individual without a good level of financial literacy is not likely to be well placed to manage own financial affairs prudently. Poor financial choices, based on a lack of understanding of financial matters, can result in negative outcomes, including a lower level of financial wealth and imprudent debt levels. Williams (2016) maintains that a more financially literate society has the capacity to exert stronger market discipline on financial service providers by exercising greater scrutiny over the risks of particular financial institutions and their products, and through a greater awareness of risk-return trade-offs. Accordingly, as pointed by Diniz et al. (2012), a stronger level of financial literacy among consumers of banking services leads to more disciplined, sound and efficient financial institutions.

Unlike the developed world, the financial literacy rate in Africa is lagging (Kojo \& Oseifuah, 2010). The implication could be that the majority of customers do not know the procedures to be followed when transacting with banks. Even when given good products, the lack or inadequate technical skills to utilize them may result in clients not accessing the required banking services. Additionally, mass media and other avenues for advertisement promoting the usage of banks for transactions often employ mono-language to reach all types of potential customers resulting in absolute knowledge on the necessity of bank services being distorted. This way the relevance of using bank services is lost to many would be clients. In most of the less developed countries of Sothern 
Africa, public infrastructures such as schools and other social enlightenment facilities are below the optimal to allow widespread financial literacy, which is necessary for spurring the use of banking services.

\subsection{Inadequate client protection}

Most people in these countries have witnessed private assets being attached or repossessed by banks. There is no clear information given to the public on these bank attachments or repossessions. This results in a high degree of public mistrusts of banks. From the foregoing, an enormous number of inexperienced and vulnerable customers implies the need for more attention to consumer protection. Yet, banks in Southern Africa because of their origin and a number form a sort of cartel to co-ordinate policies in areas such as interest rates, exchange rates and customer policies effectively turning the banking sector into what Penrose (2013) calls a de facto sellers' market with no accountability to customers, shareholders and the general public. Certainly, such complacent and inefficient behavior in the delivery of services may not go down well with the clients who may view the banks as not caring about their needs. Absence of statutory requirement for banks to publish their financial statements so that customers can know the financial position and capabilities of the banks that they are transacting with can, according to Stevenson and Wolfers (2011), lead to public mistrust of financial institutions.

\subsection{Low income customers}

Inhabitants of rural communities are in the low income group. Besides the income being very low, the frequency at which they get this little income poses a problem. These people are not sure when they will get their next income. Literature (for example, Allen et al., 2012) is clear about the factor of income on the use of a banking system in a country. Invariably, income necessitates cash flow to individuals. Implied here is the dilemma faced by many poor people in deciding whether to use the banking system or not (Efobi, Beecroft, \& Osabuohien, 2014). In reality, this decision depends primarily on push factors such as low incomes among the country's citizens. As such, banks find it difficult to extend services at a profit to such clients. Certainly, the cost-benefit equa- tion of serving the low income clients often forces their exclusion, since the profitability and capability of the banks to offer better services may be undermined. Some factors that can improve access to and use of bank services include regularity of income of potential bank customers, improved employment status, financial literacy and appropriate means of identification (Ladipo, 2012).

\subsection{Customer attitude and culture towards banking services}

A significant number of potential banking clients in Southern African countries do not find it necessary to keep their money in the bank and prefer to keep it in trunks, in holes or under mattresses and pillows at home. The thinking one should be able to use own money anytime one wants without having to go and queue for one's money. Generally, the blame should be placed squarely on the banks themselves who are not innovative enough to offer their clients good customer service. In addition, people see the use of banks as not adding any value to them because of the entailed banking charges as opposed to the interest earned for the savings. This is indicative of Southern Africa's lower saving culture. This makes it quite costly for banks to try and mobilize funds through savings in Southern African countries. With the majority of customers in Southern African countries being unable to access radio and television broadcasting services and newspapers, it has become difficult for them to receive promotional messages on the convenience entailed in the use of plastic money. If anything, they do not believe that it is as real as their money they would have deposited in the banks. As such, there is generally a negative attitude to plastic cards which do not indicate how much has unlike the traditional passbooks that one would use as evidence of how much wealth one had to friends and relatives.

\subsection{Limited institutional capacity among banks}

In Southern African countries, most of the banks display weak institutional capacity to allow all that seek to use the banking system an easy access and adequate protection. Cases of fragile banking institutions getting closed without compensation to the banking public cause many to avoid using banking systems. To many of the urban and ru- 
ral clients, saving with a bank is very risky. At the same time, this fragility in institutional capacity is observable when banks fail to effectively and efficiently intermediate between the saving publics and those investors who need money for their projects. This, coupled with other factors, for instance, lack of collateral, inadequate credit information, and fragile legal structures hinders the effective use of the Southern African countries' banks. This is in line with Khan and Senhadji (2000) who argued that people's use of a country's banking system is dependent on the level of development and efficiency of that country's banks.

\subsection{Limited understanding of client needs}

A major feature of the banking systems in these developing countries is that most operating banks still use policies that have been formulated from the external operating environment. Implied here is the lack of recognition by banks on the need to adapt to the changed demands of the new environment. The new clients in the developing countries increasingly consider different factors in their buying decisions, including the quality of the relationship, the on-board experience, and the technical ability to deliver products and services seamlessly using effective, integrated client data management tools. This means that the essentiality of increased considerations of client needs, that is, the right product at the right price. Literature reveals these as the table stakes for banking system use. Customer research shows that this experience shapes a customer's perception of the bank for years to come. Issues at the start of a relationship can linger in clients' minds well into the future.

\subsection{Political interference}

Many of Southern African countries' central banks are controlled by governments that follow populist public policies to pacify the restive populations. This means that the political interventions are dictating the way banks are managed. This has hampered banks' ability to innovate in terms of building stronger institutional infrastructure, know-how and technology to better serve their customers. Increased political interference in Southern Africa's banking systems has caused the crowding out of private consumption of financial services by the public sector borrowings. This, together with the not so well liberalized markets, tends to facilitate lesser competition resulting in banks failing to service the majority of people. Participants from all the Southern African countries acknowledge high levels of political interference in the countries' banking systems. This has led to massive corruption in credit allocation. Lastly, issue of political control on interest rates and exchange rates blocks the banking systems' ability to mobilize and allocate capital efficiently.

\subsection{Insufficient infrastructure}

There is no sufficient infrastructure in these Southern African states. Without adequate infrastructure, banks would continue to struggle to meet the needs of their customers. Poor and inadequate power supply system, telecommunications and road networks have empirically been found to impede the use of the banking system by the citizens (Chakravarty \& Pal, 2013). Indeed, insufficient infrastructure diminishes the banks' ability to increase their spread of delivery sites to socially and geographically disadvantaged people.

\subsection{Social constraints}

According to the participants, some religious and traditional faiths honour some days as sacred and thus forbid their followers to use or touch money on such days. In Southern Africa, banks are open from Monday to Saturday. Since these people will be busy from Monday to Friday, this usually forces them to withdraw everything when they get to the bank. There is also a prevalence in Southern Africa of people not having appropriate means of identification, adequate information about the benefits of banking systems and lack of initial capital to open a saving account. Added to these are technical constraints, for instance, absence of credit rating bureaus to gather intelligence regarding the credit history of potential borrowers thus exacerbating the caution exhibited by banks and financial institutions in lending to the indigenous people in the countries of Southern Africa. Furthermore, public mistrust of banking institutions is very high implying that citizens tend to favor alternative methods of saving their funds such as cooperative societies and association savings among others. 


\subsection{New bank account requirements}

Most banks in these six countries require proof of address, valid identity document, proof of employment and proof of a previous bank or current account elsewhere. These requirements are very difficult, as most of the rural settlements are informal settlements with no postal or unique identifiable residential address. Some of the migrant workers in these settlements work illegally and do not have a valid form of identification.

\subsection{Bank charges}

Some of the bank accounts in these countries are expensive to maintain, a good example is the cheque or current account. These charges when summed per month are significant to the extent that those in the low income group prefer to be given cash by their employers than salaries through banks. There is a need for banks to investigate these cases and find ways to accommodate these low income groups.

\section{CONCLUSION}

People are unwilling to bank their money in rural Southern Africa and the reasons behind this seem to be many. This is of concern and if no correctional measures are put in place, rural Southern Africa will continue to be unbanked for the next five decades. The issue of new bank account requirements requires revision. One is opening his or her first bank account, then, is asked for previous banking details. In rural Southern Africa, most people use nearest schools as their postal addresses. These are not acceptable to banks as proof of address in Southern Africa. What is surprising is that some government departments such a police, courts, clinics and hospitals accept this form of postal or residential address. As for some religious reasons that are preventing children from accessing secondary education, we encourage the various governments to engage nongovernmental organizations, other international bodies such as UNICEF or UN for help to educate and convince these societies on the importance of education. According to the participants in the focus groups, some religious groups have gone to the extent of banning the TV, radio and even cell phones from church members. How can we learn and improve without these? Most new services and products get to the public through these channels. The issue of infrastructure is one of those reasons that makes Southern Africa incapable of catching up with the rest of the world within the next five or so decades. According to participants some of the settlements are not accessible in the rain seasons. Even though democracy is gaining ground slowly in Southern Africa we still have a lot to learn from the developed world. In addition, some of the government policies on banks that may work in the developed world are not necessary or suitable in Southern Africa. As for bank repossessions or attachments, participants were very unhappy. They pointed out some cases of bank repossessions or attachments where banks use very small and insignificant outstanding balances such as US $\$ 100$ as a reason to auction a client's property such as a house or a motor vehicle. These are serious cases that are causing serious public mistrusts of banks and must be explored by Southern African governments so as to protect bank customers.

\section{REFERENCES}

1. Aduda, J., \& Kalunda, E. (2012). Financial inclusion and financial sector stability with reference to Kenya: A review of literature. Journal of Applied Finance and Banking, 2(6), 95. Retrieved from http://www.scienpress.com/journal_focus.asp?main_id=56\&Sub $\mathrm{id}=$ IV \&Issue $=466$
2. Ali, M. S. B. (Ed.) (2016). Economic Development in the Middle East and North Africa: Challenges and Prospects. Springer. Retrieved from http://nwulib.nwu.ac.za/ login?url=http://link.springer. com/10.1057/9781137480668
3. Aljawarneh, S., Al-Rousan, T., Maatuk, A. M., \& Akour, M. (2014). Usage of data validation techniques in online banking: A perspective and case study. Security Journal, 27(1), 27-35. http://dx.doi.org.nwulib.nwu. ac.za/10.1057/sj.2012.10 
4. Allen, F., Demirgüç-Kunt, A., Klapper, L., \& Peria, M. S. M. (2016). The foundations of financial inclusion: Understanding ownership and use of formal accounts. Journal of Financial Intermediation, 27, 1-30. http://dx.doi.org/10.1016/j. jfi.2015.12.003

5. Allen, F., Demirgüç-Kunt, A., Klapper, L. F., \& Martinez Peria, M. S. (2012). The foundations of financial inclusion: Understanding ownership and use of formal accounts.

6. Anyanwu, J. C. (2014). Factors affecting economic growth in Africa: are there any lessons from China? African Development Review, 26(3), 468-493. http:// dx.doi.org/10.1111/14678268.12105

7. Ashraf, N., Karlan, D., \& Yin, W. (2010). Female empowerment: Impact of a commitment savings product in the Philippines. World development, 38(3), 333-344. https://doi.org/10.1016/j.worlddev.2009.05.010

8. Baumol, W. J., Litan, R. E., \& Schramm, C. J. (2007). Good capitalism, bad capitalism, and the economics of growth and prosperity. http://dx.doi. org/10.2139/ssrn. 985843

9. Bayero, M. A. (2015). Effects of Cashless Economy Policy on financial inclusion in Nigeria: An exploratory study. Procedia-Social and Behavioral Sciences, 172, 49-56. http://dx.doi.org/10.1016/j. sbspro.2015.01.334

10. Beck, A., Demirgüç-Kunt, S., Martinez, P. (2008). Banking services for everyone? Barriers to bank access and use around the world. World Bank Econ. Rev., 22(3) (2008), 397-430. https:// doi-org.nwulib.nwu.ac.za/10.1093/ wber/lhn020

11. Beck, T., Senbet, L., \& Simbanegavi, W. (2014). Financial inclusion and innovation in Africa: An overview. Journal of African Economies, 24(suppl_1), i3-i11. https://doi.org/10.1093/jae/ eju031
12. Benamati, J., \& Serva, M. A. (2007). Trust and distrust in online banking: Their role in developing countries. Information Technology for Development, 13(2), 161-175. http://dx.doi. org/10.1002/itdj.20059

13. Berger, A. N., Bouwman, C. H., Kick, T., \& Schaeck, K. (2016). Bank liquidity creation following regulatory interventions and capital support. Journal of Financial Intermediation, 26, 115-141. https://doi.org/10.1016/j. jfi.2016.01.001

14. Brevoort, K. P., \& Wolken, J. D. (2009). Does distance matter in banking? In The changing geography of banking and finance (pp. 27-56). Springer US.

15. Bruhn, M., \& Love, I. (2009). The economic impact of banking the unbanked: evidence from Mexico.

16. Bruhn, M., \& Love, I. (2014). The real impact of improved access to finance: Evidence from Mexico. The Journal of Finance, 69(3), 1347-1376. http://dx.doi. org/10.1111/jofi.12091

17. Burgess, R., Pande, R., \& Wong, G. (2005). Banking for the poor: Evidence from India. Journal of the European Economic Association, 3(2-3), 268-278. https://doi-org.nwulib.nwu. ac.za/10.1162/jeea.2005.3.2-3.268

18. Cámara, N., \& Tuesta, D. (2014). Measuring Financial Inclusion: A Muldimensional Index. http:// dx.doi.org/10.2139/ssrn.2634616

19. Chakravarty, S. R., \& Pal, R. (2013). Financial inclusion in India: An axiomatic approach. Journal of Policy Modeling, 35(5), 813-837. https://doi.org/10.1016/j. jpolmod.2012.12.007

20. Cruz, P., Barretto Filgueiras Neto, L., Muñoz-Gallego, P., \& Laukkanen, T. (2010). Mobile banking rollout in emerging markets: Evidence from Brazil. International Journal of Bank Marketing, 28(5), 342-371. https://doi. org/10.1108/02652321011064881

21. Demirgüç-Kunt, A., \& Klapper, L. (2013). Measuring financial inclusion: Explaining variation in use of financial services across and within countries. Brookings Papers on Economic Activity, 2013(1), 279-340. Retrieved from http:// www.jstor.org.nwulib.nwu.ac.za/ stable/23594869

22. Demirgüç-Kunt, A., \& Klapper, L. F. (2012). Measuring financial inclusion: The global findex database. Retrieved from https:// ssrn.com/abstract $=2043012$

23. Demirgüç-Kunt, A., \& Maksimovic, V. (1998). Law, finance, and firm growth. The Journal of Finance, 53(6), 21072137.

24. Demirgüç-Kunt, A., Klapper, L., \& Randall, D. (2014). Islamic finance and financial inclusion: measuring use of and demand for formal financial services among Muslim adults. Review of Middle East Economics and Finance, 10(2), 177-218. https:// doi-org.nwulib.nwu.ac.za/10.1515/ rmeef-2013-0062

25. Diniz, E., Birochi, R., \& Pozzebon, M. (2012). Triggers and barriers to financial inclusion: The use of ICT-based branchless banking in an Amazon county. Electronic Commerce Research and Applications, 11(5), 484494. https://doi.org/10.1016/j. elerap.2011.07.006

26. Efobi, U., Beecroft, I., \& Osabuohien, E. (2014). Access to and use of bank services in Nigeria: Micro-econometric evidence. Review of development finance, 4(2), 104-114. https://doi. org/10.1016/j.rdf.2014.05.002

27. Ehrmann, M., Soudan, M., \& Stracca, L. (2013). Explaining European Union citizens' trust in the European Central Bank in normal and crisis times. The Scandinavian Journal of Economics, 115(3), 781-807. http://dx.doi.org/10.1111/ sjoe. 12020

28. Ellis, A. Lemma, J. Rud, A. (2010). Financial Inclusion and Household Investment and Growth in Kenya and Tanzania. Overseas Development Institute. Project Briefing No. 43. 
29. Ellis, L., \& Smith, K. (2010). The global upward trend in the profit share. Applied Economics Quarterly, 56(3), 231-255. https:// doi.org/10.3790/aeq.56.3.231

30. Felici, R., \& Pagnini, M. (2008). Distance, bank heterogeneity and entry in local banking markets. The Journal of Industrial Economics, 56(3), 500-534. http:// dx.doi.org/10.1111/j.14676451.2008.00357.x

31. Figart, D. M. (2013). Institutionalist policies for financial inclusion. Journal of Economic Issues, 47(4), 873-894. http://dx.doi.org/10.2753/JEI00213624470404

32. Huizinga, H., \& Demirgüç-Kunt, A. (2011). Are banks too big to fail or too big to save? International evidence from equity prices and CDS spreads. https://doi. org/10.1016/j.jbankfin.2012.10.010

33. Hurley, R., Gong, X., \& Waqar, A. (2014). Understanding the loss of trust in large banks. International Journal of Bank Marketing, 32(5), 348-366. https://doi-org.nwulib. nwu.ac.za/10.1108/IJBM-01-20140003

34. Huston, S.J. (2010). Measuring financial literacy. Journal of Consumer Affairs, 44(2), 296-316. http://dx.doi.org/10.1111/j.17456606.2010.01170.x

35. Johnson, S., \& Williams, R. (2013). The political economy of financial inclusion: Working with governments on market development (No. 23). Bath Papers in International Development and Wellbeing. Retrieved from http:// hdl.handle.net/10419/128118

36. Kefela, G. T. (2010). Promoting access to finance by empowering consumers-Financial literacy in developing countries. Educational Research and Reviews, 5(5), 205. Retrieved from http://www. academicjournals.org/article/article1379607640_kefela.pdf

37. Kim, J. H. (2016). A Study on the Effect of Financial Inclusion on the Relationship between Income Inequality and Economic Growth. Emerging Markets Finance and Trade, 52(2), 498-512. http:// dx.doi.org.nwulib.nwu.ac.za/10.10 80/1540496X.2016.1110467

38. Kiviat, B., \& Morduch, J. (2012). From financial literacy to financial action. Financial Access Initiative, Robert F. Wagner Graduate School of Public Service. (New York University). Retrieved from https://wagner.nyu.edu/files/faculty/publications/Financial_Literacy_WP.pdf

39. Ladipo (2012). Access to Financial Services in Nigeria 2012 Survey, Enhancing Financial Innovation and Access-EFInA. Retrieved from http://www.efina.org.ng/ourwork/research/access-to-financialservices-in-nigeria-survey/

40. Levine, R. (2005). Finance and growth: theory and evidence. Handbook of economic growth, 1 , 865-934. https://doi.org/10.1016/ S1574-0684(05)01012-9

41. Mbutor, M. O., \& Uba, I. A. (2013). The impact of financial inclusion on monetary policy in Nigeria. Journal of Economics and International Finance, 5(8), 318. http://dx.doi.org/10.5897/ JEIF2013.0541

42. McConnell, A. (2010). Policy success, policy failure and grey areas in-between. Journal of Public Policy, 30(03), 345-362. https:// doi-org.nwulib.nwu.ac.za/10.1017/ S0143814X10000152

43. McKinnon, R. I. (2010) Money and capital in economic development. Brookings Institution Press.

44. Ramji, M. (2009). Financial inclusion in Gulbarga: Finding usage in access (Center for Micro Finance Working Paper, 26).

45. Rodrik, D., \& Rosenzweig, M. (2009). Access to Finance Chapter 2, Handbook of Development Economics, 5.

46. Rousseau, P. L., \& Wachtel, P. (2011). What is happening to the impact of financial deepening on economic growth? Economic Inquiry, 49(1), 276-288. http:// dx.doi.org/10.1111/j.14657295.2009.00197.x

47. Sagib, G. K., \& Zapan, B. (2014). Bangladeshi mobile banking service quality and customer satisfaction and loyalty. Management \& Marketing, 9(3), 331.

48. Sarma, M. (2008). Index of financial inclusion. New Delhi: Indian Council for Research on International Economics Relations.

49. Triki, T., \& Faye, I. (2013). Financial inclusion in Africa. Tunis, Tunisia: African Development Bank. Retrieved from http://www.microfinancegateway.org/sites/default/files/ mfg-en-paper-financial-inclusionin-africa-2013.pdf

50. Yang, A. S. (2009). Exploring adoption difficulties in mobile banking services. Canadian Journal of administrative sciences, 26(2), 136. http://dx.doi. org/10.1002/cjas.102

51. Zhang, J., Wang, L., \& Wang, S. (2012). Financial development and economic growth: Recent evidence from China. Journal of Comparative Economics, 40(3), 393-412. https://doi.org/10.1016/j. jce.2012.01.001

52. Zins, A., \& Weill, L. (2016). The determinants of financial inclusion in Africa. Review of Development Finance, 6(1), 46-57. https://doi. org/10.1016/j.rdf.2016.05.001

53. Zucarro, M., \& Bridwell, L (2016). July. Financial Inclusion and the Payments Industry. In Competition Forum, 14(2), 237. American Society for Competitiveness. Retrieved from http://eds.b.ebscohost.com. nwulib.nwu.ac.za/ehost/detail/ detail? vid $=0 \&$ sid $=1$ bea $23 \mathrm{~cd}-64 \mathrm{be}-$ 434f-bfb2-c376e16c8912\%40ses sionmgr 102\&bdata $=\# \mathrm{db}=\mathrm{s} 3 \mathrm{~h} \&$ $\mathrm{AN}=119212094$ 